DOI: https://doi.org/10.31392/NZ-npu-145.2019.11

УДК 378.016:81’243

Мішак В. М., Варга Л. І., Кравченко Т. М.

\title{
ШЛЯХИ ПІДВИЩЕННЯ ЕФЕКТИВНОСТІ НАВЧАННЯ НІМЕЦЬКОЇ МОВИ ЯК ДРУГОЇ ІНОЗЕМНОÏ НА БАЗІ АНГЛІЙСЬКОї МОВИ У ВНЗ
}

\begin{abstract}
У статті проаналізовано ступінь розробленості досліджуваної проблеми у педагогічній теорії та практиці; розглянуто найбільш ефективні чинники підвищення ефективності навчання німеиької мови як другої іноземної на базі англійської у вузі. Запропоновано інноваційні технологї та нові методики, які уможливлюють індивідуалізацію й диференціацію навчання $з$ урахуванням особистісних здібностей студентів. Звернено увагу на те, що головною метою сучасного викладача має бути пошук різних иляхів для підвищення мотиващії студентів, демонструючи їм позитивні сторони контакту двох мов; доказуючи у процесі роботи, щяо досвід вивчення першої мови полегшує опанування другої іноземної мови на половину за рахунок сформованих навичок та умінь в основній іноземній мові, проведення паралелей, порівнянь та свідомого аналізу мовних явищ та структур. Перераховано загальні принципи, що діють у змісті навчання будь-якої іноземної мови, найважливішими з яких є опора на периу іноземну мову та принципи економії й інтенсифікації навчання другої іноземної мови.

Акцентовано увагу на використання зіставних характеристик у процесі вивчення німецької й англійської мов, а саме наближеність граматичних конструкцій, функиіональність американізмів та фонетичний аспект двох германських мов; дочільність використання ком'ютерних технологій, зокрема інтернет-ресурсів на заняттях з іноземної мови, так як воно сприяє інтенсифікачії процесу навчання та дає можливість вирімувати певні дидактичні задачі, серед яких: - вдосконалення мовних компетенцій иляхом використання аутентичних матеріалів інтернет-простору; - практика монологічного та діалогічного висловлення; - залучення студентів до самостійної роботи; - спілкування з представниками інших культур, з носіями мови, яка вивчається; - реалізація диференщійного підходу до навчання тощю.
\end{abstract}

Ключові слова: ефективність навчання, друга іноземна мова, німецька мова, інтенсифікачія навчання, , інновачійна технологія.

3 кожним роком спостерігається все стрімкіший потік глобалізаційних процесів у всіх сорерах життя. Характерними ознаками цього є зростання ролі знань і переходом світової спільноти від індустріальної до інформаційної стадії свого розвитку, прагненням до універсального світу, світу без кордонів у всіх сорерах. Виняток не становить і ланка вищої освіти, основними завданнями якої $€$ підготовка універсальних кадрів і універсалізація освітнього процесу, реформування його фрорм і методів. Для реалізації низки задач, передбачених Болонським процесом, необхідно перш за все покращення викладання іноземних мов у вітчизняних вищих навчальних закладах; вдосконалення методів навчання, для випуску висококваліфікованих спеціалістів, які будуть готові до участі в міжнародному співробітництві, насамперед із Європою, де німецька мова посідає значне місце в економічному, політичному, освітньому й культурному житті. Кінцевим результатом ми бачимо сфрормованість особистості, яка є активним суб’єктом міжкультурної комунікації, готової 
компетентно продемонструвати високий рівень взаєморозуміння та взаємодії в умовах міжнародних контактів, що відповідатиме вимогам та реаліям часу . Низка сучасних педагогів лінгвістів бачать досягнення цієї мети за рахунок білінгвального та бікультурного навчання іноземних мов, яке забезпечить синтез мовного, предметного та міжкультурного компонентів в процесі підготовки студентів до професійної діяльності і являє собою базу інтернаціоналізації вищої освіти в руслі Болонського процесу.

Багатий досвід накопичений вищою школою з питань організації та оптимізації навчання відобразили у своїх працях відомі вітчизняні науковці такі як Р.Гуревич, Ю. Бабанський. Над виявленням чинників, що визначають ефрективність процесів навчання й виховання, завдяки використання педагогічних технологій працювали В.Беспалько, А. Нісімчук, О.Пєхота. Проблемами відбору, конструювання й застосування елементів змісту, методів (прийомів), а також організаційних форм навчання для досягнення дидактичних цілей займалися І.Лернер, Ю.Жук. Розробка основних теоретичних положень та проблеми організації навчального процесу з другої іноземної мови належить В. Горіній та Б. Лебединській. Велику цінність мають практичні рекомендації Б. А. Лапідуса, який дослідив специфічні умови вивчення і викладання другої іноземної мови, які мають загальний характер та однаковою мірою стосуються вивчення всіх пар мов: англійської і німецької, англійської і французької та інших, не враховуючи особливості співвідношення їх мовних систем. Світову педагогічну практику систем освіти порівнювала Н. Ракова. Педагогічні й теоретичні аспекти використання інформаційних технологій та доцільність їх використання у навчальному процесі досліджені у працях А. Кушніренка та А. Леонова.

Згідно державного стандарту про вищу освіту України іншомовна профресійна компетенція є обов'язковим компонентом професійної компетенції будь якого сучасного фахівця. В порівнянні із західною Європою, де переважна більшість освічених громадян вільно володіють двома чи трьома іноземними мовами, в нашій країні поки що відсутня традиція масового володіння іноземними мовами, що завдає труднощів при вивченні другої та третьої іноземної мови у вузі. Однією з проблемою під час навчання часто випливає мотиваційний аспект. Чимало вітчизняних студентів посилаються на той фракт, що саме англійська мова є мовою міжнародного спілкування, а отже німецькою не обов'язково добре володіти; німецька мова граматично та лексично важча (за рахунок багатокомпонентних слів і т.д). Дійсно, у німецькій мові $є$ багато тем, які відміну англійської мови на будь-якому рівні викликають певні труднощі у студентів, передусім це вживання та відмінювання артикля; відмінювання прикметників; утворення і вживання пасивного стану дієслів; утворення і вживання форм умовного способу; порядок слів у німецькому реченні, особливо у складнопідрядному. Та головною метою сучасного викладача має бути пошук різних шляхів для підвищення мотивації студентів, показати їм позитивні сторони контакту двох мов; доказати у процесі роботи, що досвід вивчення першої мови полегшує опанування другої іноземної мови на половину за рахунок сформованих навичок та умінь в основній іноземній 
мові, проведення паралелей, порівнянь та свідомого аналізу мовних явищ та структур. Ефективність викладання другої IM залежить і від того, наскільки вміло викладач використовує перенос навичок і прийомів, раніше засвоєних студентами в ході навчання першої іноземної мови. Врахування специфіки міжмовного переносу звичайно не вирішить всі проблеми навчання другої іноземної мови, але його об'єктивне врахування, а головне - правильне використання, чимало сприяє успішному розв'язанню важливої проблеми навчання другої іноземної мови - підвищенню його мотиваційної основи.

Досвід попереднього вивчення першої ІМ підказує студентам наскільки нелегко оволодіти іноземною мовою. Це викликає у багатьох із них зневіру в можливість в умовах обмеженої кількості навчальних годин, що відведено на вивчення другої іноземної мови, оволодіти нею хоча 6 у віддаленому наближенні так, як першою іноземною. Ця обставина гостро ставить питання про внутрішню мотивацію вивчення іноземних мов. Вона, як відомо, багато в чому пов'язана зі створенням у тих, хто навчається, усвідомлення досягнутих успіхів. Таким чином, мовний перенос дає можливість інтенсифікувати процес навчання, заощадити час, що завжди важливо при вивченні іноземних мов та створює простір для подальшого більш поглибленого вивчення другої іноземної мови.

На думку сучасного німецького мовознавця Брітти Гуфайзен процес вивчення другої іноземної мови, в даному випадку німецької мови після англійської не відхиляється від традиційної глотодидактики, а тільки розширюється завдяки новим аспектам та перспективам, а саме:

- когнітивного вчення та навчання - порівняння мов, обговорення відмінностей та досвіду викладання;

- розуміння основ вивчення мови - запис та обробка інформації, закріплення нових даних у мозку, активізація знань;

- змістової орієнтації - автентичні, правильно підібрані матеріали, які відповідають інтересам студентів;

- текстової орієнтації - розвиток мовних систем, розвиток глобальних стратегій читання та розробка стратегій вибіркового читання;

- економізації навчального процесу - підбір ефективних процесів навчання та викладання, активізація та мотивація студентів [7, с. 41-45].

Удосконалення методів навчання другої іноземної мови - одне 3 актуальних завдань як теорії, так і практики навчання іноземних мов. Як правило викладання другої іноземної мови відбувається на основі тих самих принципів, які використовують при оволодінні першою іноземною мовою, але через меншу кількість годин. Вітчизняні науковці в галузі методики викладання іноземних мов у закладах вищої освіти стверджують, що заняття з другої іноземної мови має бути набагато швидшим аніж з першої іноземної мови, а робота із вправами - інтенсивнішою; пояснення нового граматичного матеріалу має бути максимально лаконічним і стислим; доречним $\epsilon$ застосування граматичних та лексичних паралелей 3 першою іноземною мовою. Як свідчить практика навчання німецької мови на базі англійської, успішному оволодінню другою мовою на початковому етапі сприяють такі 
лінгвістичні особливості:

- генетична спорідненість німецької та англійської мов;

- латинська спорідненість;

- деякі спільні моменти у вимові;

- аналогічні граматичні явища, близькі за структурою та значенням;

- схожі мовленнєві зразки, що вивчають на початковому рівні [2, с. 15-17].

У процесі організації навчання німецької мови як другої іноземної на базі англійської на думку Л. Дзевицької варто спиратися на загальні принципи, що діють у змісті навчання будь-якої іноземної мови. Найбільш суттєвими принципами $€$ такі: 1.Як і в процесі навчання будь-якій іноземній мові, комунікативні цілі зумовлюють загальний методичний підхід до навчання. Водночас оскільки студенти вже мають досвід вивчення першої іноземної мови, оволодіння другою здійснюється ними більш свідомо; відповідно, студенти можуть порівнювати як певні мовні явища першої і другої іноземних мов, так і організацію процесу навчання. У студентів, які вивчають дві іноземні мови, більш розвинена рефлексія, яка виявляється в умовах, де треба знайти будь-які аналогії, що полегшують засвоєння, або, навпаки, виявити відмінності, щоб уникнути інтерференції. 2. Навчальний процес повинен бути орієнтований на особистість студента, його розвиток, самостійність, урахування його можливостей, потреб, інтересів. 3. Навчальний процес повинен мати соціокультурну спрямованість, але має місце специфіка: раннє використання автентичних матеріалів (уже з першого уроку пропонуються автентичні тексти й опора на взаємовплив трьох національних культур). 4. Робота з оволодіння конкретними мовними засобами повинна переходити в мовні дії, спрямовані на розв'язання певних комунікативних завдань, спрямованих на розвиток мовної особистості, яка виявляє себе як така, що на достатньому рівні володіє засобами мовного коду рідної мови (код - система умовних знаків, правил трансляції інформації каналами зв'язку (комунікації) відповідно до соціальнокультурних особливостей) у різних комунікативних ситуаціях. Комунікативні завдання мають бути побудовані так, щоб забезпечити процес: - комунікації вербальної (цілеспрямована психо-лінгво-ментальна діяльність учасників спілкування за допомогою мовного коду, результатом якого є інформаційний обмін, взаємовплив, тобто фрормування дискурсів); - комунікації невербальної (взаємодія між учасниками спілкування за допомогою невербальних і паравербальних (паралінгвістичних) засобів). 5. Чотири основні види мовної діяльності: аудіювання, говоріння, читання, письмо - повинні розвиватися у взаємозв'язку один із одним. Специфікою викладання другої іноземної мови $€$ те, що навчання читання з самого початку здійснюється на оригінальних текстах і має велику питому вагу, тому що студенти володіють латинським шрифтом, швидше опановують правилами читання, хоча має місце небезпека виникнення інтерференції з німецькою мовою. Вони володіють прийомами роботи з іншомовним текстом, ширше спираються на мовну здогадку. 6. Порівняльний (компаративний) підхід під час навчання другої іноземної мови також $є$ важливим. У студентів $є$ можливість виявляти різницю між мовами й шукати подібність у них. При вивченні другої 
іноземної мови суттєву допомогу надає опора на рідну мову і на першу, особливо - англійську мову, оскільки німецька й англійська мови належать до однієї групи мов (германських). 7. Важливими $є$ принципи економії й інтенсифікації навчання іноземної мови. Процес оволодіння другою іноземною мовою може бути значно інтенсифікованим, якщо студенти мають високий рівень володіння англійською мовою [3, с. 252]. Інтенсифікація початкового етапу навчання і загалом навчального процесу в цілому $\epsilon$ важливою передумовою його успішності й результативності

Під час вивчення німецької й англійської мов на основі зіставних характеристик варто враховувати фрункціональність американізмів (Tеam, Cool), наближеність граматичних конструкцій (Ich gehe zur Schule. I go to school.) та фронетичний аспект (mine - mein, mouse - die Maus, telephone - das Telefon).

Новими методами вивчення іноземних мов на порівняльній основі активно займається В. Біркенбіль. Вивчення іноземної мови за "Методикою Біркенбіль", яка 3 кожним роком набуває популярності не тільки у європейському освітньому просторі,але і на нашій батьківщині, включає кілька основних етапів:

- Послівне дешифрування тексту. (A fat guy is rolling down the street. Ein fett Kerl is rolling runter die Strasse. Спочатку вгадуємо значення слів, потім звіряємо їх з словником).

- Читання перекодованого тексту і одночасне прослуховування його (проводимо фонетичне порівняння).

- Прослуховування тексту як фону, під виконання інших видів робіт (текст прослуховується до тих пір, поки він не буде зрозумілим без перекладу).

- Робота в тандемі, де один учасник $€$ німецькомовним, а інший англомовним (складання діалогів, підготовка презентації, міжнародне листування). Саме з цієї методики проект “Тандем: Вдвох все таки краще” ще в 2007 році отримав Європейську медаль як кращий інноваційний проект року у сорері вивчення іноземних мов.

На нашу думку, цю методику варто впроваджувати на початковому етапі вивчення другої іноземної мови, так як вона робить навчальний процес більш облегшеним, ті, хто вивчають нову мову мають змогу швидко бачити позитивний результат, що $є$ доброю мотиваційною основою для подальшої роботи.

Сучасний студент зацікавлений передусім у швидкості та широкомасштабності то ж використання ком'ютерних технологій, зокрема інтернет-ресурсів на заняттях з іноземної мови повинно займати чинне місце, так як воно сприяє інтенсифрікації процесу навчання та дає можливість вирішувати певні дидактичні задачі, серед яких: - вдосконалення мовних компетенцій шляхом використання аутентичних матеріалів інтернет-простору; - практика монологічного та діалогічного висловлення; - залучення студентів до самостійної роботи; - спілкування 3 представниками інших культур, з носіями мови, яка вивчається; - реалізація дифреренційного підходу до навчання тощо. Незважаючи на всі суб'єктивні та 
об'єктивні труднощі при викладанні та оволодінні німецькою мовою як другою іноземною більшість студентів мають високий інтелектуальний та лінгвістичний потенціал щодо вивчення мови і для підвищення свого фахового рівня можуть брати участь в електронних формах діагностування і навчання (тестування, он-лайн конференції, конкурси, створення веб сторінок та навчальних платформ).

Викладене вище дозволяє зробити висновок про те, що ефективність викладання німецької мови в зіставленні з англійською залежить і від того, наскільки вміло викладач використовує перенесення навичок і прийомів, раніше засвоєних студентами в ході навчання першої іноземної мови. При цьому особливо важливим $€$ підбір сучасного й аутентичного матеріалу, що сприяє розвитку мотивації та свідчить про актуальність обраної мови, їі популярність. При відборі сучасних методів навчання необхідно враховувати критерії, відповідно до яких використовуванні методи сприяють: створенню атмосфері, у якій студент відчуває себе комфортно; розвитку бажання у студента практично користуватися іноземною мовою; розвиткові творчих здібностей; створенню ситуацій, у яких студент повинен усвідомлювати, що вивчення іноземної мови пов'язане з його майбутньою професійною діяльністю; спрямуванню студента на самостійну роботу над вивченням мови; застосуванню різних фрорм роботи.

Перспектива подальших досліджень у даній проблематиці займає вагоме місце, так як концепція багатомовності $€$ дуже актуальною в сучасному світі, де знання тільки однієї іноземної мови недостатньо. Враховуючи сучасний стан міжнародних зв'язків України та її шлях до європейського освітнього простору, володіння іноземними мовами допоможе відкривати на глобусі нові ринки й відкривати нові можливості. Як стверджує 3. Бауман, "в сучасному світі накопичувати варто лише можливості”. Чим більше можливостей ти маєш, тим багатшим ти є. Можливість спілкуватись іноземною мовою має бути в багажі сучасної людини обов язково, незважаючи на "текучість" нашої дійсності.

\section{Використана література:}

1. Бориско Н. Ф. Теоретичні основи створення навчально-методичних комплексів для мовної міжкультурної підготовки вчителів іноземних мов (на матеріалі інтенсивного навчання німецької мови) : дис. ... докт. пед. наук : 13.00 .02 / Київськ. держ. лінгв. ун-т. Київ, 2000. 508 с.

2. Буленок С., Коваленко Л. Інноваційні методи навчання іноземній мові у ВНЗ. Міжнародний досвід у викладанні іноземних мов: тези доповідей. Київ: Київський національний торговоекономічний університет, 2015. С. 15-17.

3. Дзевицька Л. Особливості навчання німецької мови як другої іноземної на базі англійської мови студентів-економістів. Педагогічні науки: теорія, історія, інноващійні технології : зб. наук. праць. № 4(68). 2017. С. 252-254.

4. Загальноєвропейські Рекомендації з мовної освіти : вивчення, викладання, оцінювання / наук. ред. укр. видання д-р пед. наук, проф. С. Ю. Ніколаєва. Київ : Ленвіт, 2003. 273 с.

5. Лапидус Б. А. Обучение второму иностранному языку как специальности. Москва : Высшая школа, 1980. $216 \mathrm{c}$.

6. Кушніренко А. Г., Леонов А. Г. Що таке Інтернет? Інформаційні і комунікаційні технології в освіті. Інформатика і освіта. Київ, 1998. № 5. С. 7-15.

7. Hufeisen Britta. Deutsch als zweite Fremdsprache. Deutsch als zweite Fremdsprache. S. 4-6, 52-53.

8. Krumm Heinrik. Fachlexikon Deutsch als Fremd- und Zweitsprache. Grundbegriffe der Spracherwerbsforschung. Tübingen und Basel : A. Francke Verlag. № 7. 2010. S. 38-44. 


\section{References:}

[1] Borysko N. F. Teoretychni osnovy stvorennia navchalno-metodychnykh kompleksiv dlia movnoi mizhkulturnoi pidhotovky vchyteliv inozemnykh mov (na materiali intensyvnoho navchannia nimetskoi movy) : dys. ... dokt. ped. nauk : 13.00.02 / Kyivsk. derzh. linhv. un-t. Kyiv, 2000. 508 s.

[2] Bulenok S., Kovalenko L. Innovatsiini metody navchannia inozemnii movi u VNZ. Mizhnarodnyi dosvid u vykladanni inozemnykh mov : tezy dopovidei. Kyiv : Kyivskyi natsionalnyi torhovo-ekonomichnyi universytet, 2015. S. 15-17.

[3] Dzevytska L. Osoblyvosti navchannia nimetskoi movy yak druhoi inozemnoi na bazi anhliiskoi movy studentiv-ekonomistiv. Pedahohichni nauky: teoriia, istoriia, innovatsiini tekhnolohii : zb. nauk. prats. № 4(68). 2017. S. 252-254.

[4] Zahalnoievropeiski Rekomendatsii z movnoi osvity : vyvchennia, vykladannia, otsiniuvannia / nauk. red. ukr. vydannia d-r ped. nauk, prof. S. Yu. Nikolaieva. Kyiv : Lenvit, 2003. 273 s.

[5] Lapidus B. A. Obuchenie vtoromu inostrannomu yazyku kak specialnosti. Moskva : Vysshaya shkola, 1980.216s.

[6] Kushnirenko A. H., Leonov A. H. Shcho take Internet? Informatsiini i komunikatsiini tekhnolohii v osviti. Informatyka i osvita. Kyiv, 1998. № 5. S. 7-15.

[7] Hufeisen Britta. Deutsch als zweite Fremdsprache. Deutsch als zweite Fremdsprache. S. 4-6, 52-53.

[8] Krumm Heinrik. Fachlexikon Deutsch als Fremd- und Zweitsprache. Grundbegriffe der Spracherwerbsforschung. Tübingen und Basel : A. Francke Verlag. № 7. 2010. S. 38-44.

МИШАК В., ВАРГАЛ., КРАВЧЕНКО Т. ПУти повышения эффективности обучения немецкого языка как второго иностранного на базе английского языка у высших учебных заведениях.

В статье проанализирована степень разработанности исследуемой проблемы 6 педагогической теории и практике; рассмотрены наиболее эффективные факторы повышения эффективности обучения немецкому языку как второму иностранному на базе английского в вузе. Предложено инновачионные технологии и новые методики, которые позволяют индивидуализачию и дифференциащию обучения $c$ учетом личностных способностей студентов. Обращено внимание на то, что главной целью современного преподавателя должен быть поиск различных путей для повышения мотиваџии студентов, демонстрируя положительные стороны контакта двух языков; доказывая в прочессе работы, опыт изучения первого языка облегчает овладение второго иностранного языка на половину за счет сформированных навыков и умений в основной иностранном языке, проведение параллелей, сравнений и сознательного анализа языковых явлений и структур. Перечислено общие принцииь, действующие в содержании обучения любого иностранного языка, важнейшими из которых являются опора на первыц иностранный язык $и$ принципы экономии и интенсификации обучения второму иностранному языку.

Акцентировано внимание на использование сопоставимых характеристик в процессе изучения немечкого и английского языков, а именно близость грамматических конструкций, функииональность американизмов и фонетический аспект двух германских языков; целесообразность использования комъютерних технологий, в частности интернет-ресурсов на занятиях по иностранному языку, так как оно способствует интенсификации процесса обучения и дает возможность решать определенные дидактические задачи, среди которых: - совершенствование языковых компетенций путем использования аутентичных материалов интернет-пространства; - практика монологической высказывания; - привлечение студентов к самостоятельной работе; - общение с представителями других культур, с носителями изучаемого языка; - реализация дифференцированного подхода к обучению и тому подобное.

Ключевые слова: эффективность обучения, второй иностранный язык, немецкий язык, интенсификация обучения, инновационная технология. 
MISHAK V., VARGA L., KRAVCHENKO T. Ways to increase the efficiency of teaching the German language as a second foreign on the basis of the English language at higher educational institutions.

The degree of development of the investigated problem in pedagogical theory and practice has been analyzed in the article; the most effective factors of increasing the effectiveness of teaching German as a second foreign language based on English at a university have been considered. Innovative technologies and new techniques have been proposed that allow individualization and differentiation of training, taking into account the personal abilities of students. Attention has been drawn to the fact that the main goal of a modern teacher should be to search for various ways to increase students' motivation, demonstrating the positive aspects of contact between two languages; proving in the process of work, the experience of learning the first language facilitates the mastery of the second foreign language by half due to the formed skills in the main foreign language, drawing parallels, comparisons and a conscious analysis of linguistic phenomena and structures. The general principles that are valid in the content of teaching any foreign language have been listed, the most important of which are relying on the first foreign language and the principles of economy and intensification of teaching a second foreign language.

Attention has been focused on the use of comparable characteristics in the process of studying German and English, namely the proximity of grammatical constructions, the functionality of Americanisms and the phonetic aspect of two Germanic languages; the appropriateness of using computer technologies, in particular Internet resources in foreign language classes, as it helps to intensify the learning process and makes it possible to solve certain didactic problems, including: - improving language competencies by using authentic materials from the Internet space; - practice of monologic and dialogical expression; - involvement of students in independent work; - communication with representatives of other cultures, with native speakers of the language being studied; - implementation of differential approach to learning, etc.

Keywords: learning efficiency, second foreign language, German, intensification of instruction, innovative technology, foreign language competence, multilingualism.

DOI: https://doi.org/10.31392/NZ-npu-145.2019.12

УДК 378.147

Монько Р. М.

\section{ПІДГОТОВКА ВЧИТЕЛІВ ТЕХНІКИ ТА ІНФОРМАТИКИ В УМОВАХ РЕФОРМУВАННЯ СИСТЕМИ ОСВІТИ, ПОЛЬСЬКИЙ ДОСВІД}

Сучасна система освіти в Польщі перебуває на етапі модернізащії, спрямованого на вдосконалення й організачію діяльності шкіл різних типів. Приєднання до Болонського процесу (1999 р.); приєднання до Брюгге Копенгагенського процесу (2004 р.) є початком реалізації на державному рівні виконання стратегічних изілей, які відображають загальноєвропейську політику розвитку освіти на всіх рівнях. Головне завдання перетворень в освіті - наближення ї до тих принципів, які характерні для країн Європейського Союзу. У статті розглядаються питання особливостей підготовки майбутніх вчителів техніки і інформатики у республіці Польща. Проаналізований досвід вітчизняних і польських дослідників щэодо якісної підготовки майбутніх вчителів техніки і інформатики у Польщі. У XXI столітті інформація стала важливим стратегічним ресурсом, без використання якого не існує жодна країна світу. В 